\title{
ランダムフォレストを用いた法令用語の校正
}

\section{Japanese Legal Term Correction using Random Forest}

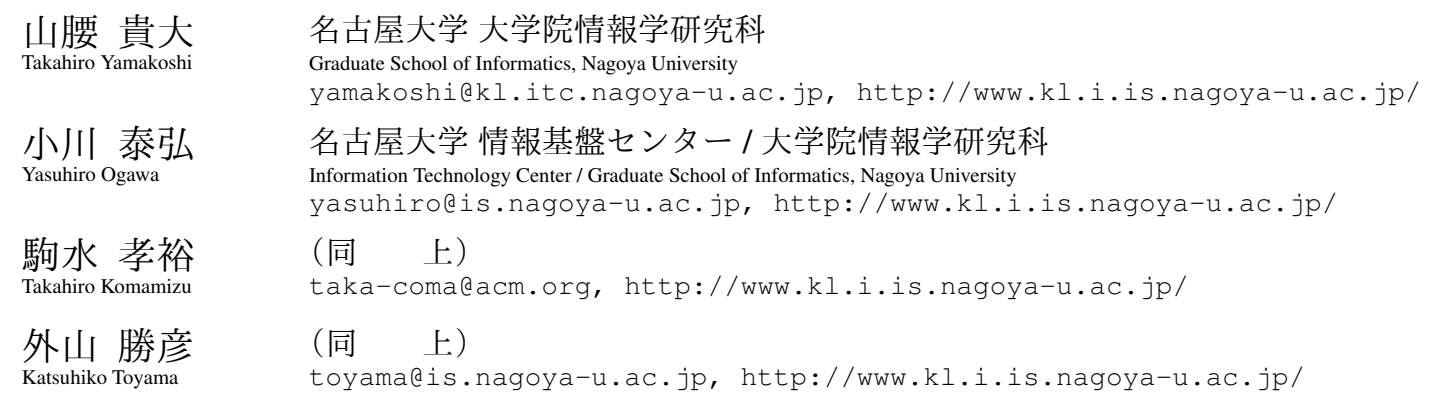

keywords: Japanese legal term, legal term correction, random forest

\section{Summary}

We propose a method that assists legislation drafters in finding inappropriate use of Japanese legal terms and their corrections from Japanese statutory sentences. In particular, we focus on sets of similar legal terms whose usages are strictly defined in legislation drafting rules that have been established over the years. In this paper, we first define input and output of legal term correction task. We regard it as a special case of sentence completion test with multiple choices. Next, we describe a legal term correction method for Japanese statutory sentences. Our method predicts suitable legal terms using Random Forest classifiers. The classifiers in our method use adjacent words to a target legal term as input features, and are optimized in various parameters including the number of adjacent words to be used for each legal term set. We conduct an experiment using actual statutory sentences from 3,983 existing acts and cabinet orders that consist of approximately 47M words in total. As for legal term sets, we pick 27 sets from legislation drafting manuals. The experimental result shows that our method outperformed existing modern word prediction methods using neural language models and that each Random Forest classifier utilizes characteristics of its corresponding legal term set.

\section{1.は じめに}

国の法令や地方自治体の例規を構成する文（法令文） には，法令文特有の意味・用法を持つ表現（法令用語）が 出現する．法令用語の中には，互いに類似しているもの があるが，その多くは厳密に使い分けられる。たとえば, 三つの法令用語「者」，「物」，「もの」は，次のように使 い分けられる.

・「者」は自然人または法人を表す際に用いる.

・「物」は「者」に含まれない有体物を表す際に用いる.

-「もの」は抽象的概念を表す際に用いる.また，あ る概念に制約を加えた概念を表す際などにも用いる.

これらの法令用語を含む法令文を図 1 に示す。図 1 にお いて，文 [1]に現れる「者」は自然人や法人を表す一方， 文 [2]に現れる「物」は自然人や法人ではない有体物を表 す. また,「もの」について, 文 [2]の「もの」は「蓄音機 用音盤、録音テープその他の物」に「音を固定する」と いう制約を加えた概念を表す（そのため，空の録音テー プはこの概念から除外される）が，文 [3]に現れる「も
の」は単に抽象的概念であることを表す。

日常で一般に用いられている文において，「もの」と 「物」，および,「もの」と「者」は，それぞれニュアンス や文体に応じて比較的自由に交換できるが，法令文にお いてこれらの語を自由に交換することはできない．たと えば,「著作者 著作物を創作するもの」と記述すると， 「もの」の定義上，どのような人や法人も「著作者」とな らなくなり，意味が通らない.

法令文における用語の使い分けは，法制執務（法令の 起草・制定・改廃など法令文書の作成・管理に関する業務) に必要な技術の一つである，わが国の法制執務は，明治 期以来，長年にわたって培われた慣習や規則（以降，法 制執務規則という）に基づいて実施されており，多くの 解説書が上梓されている（たとえば，[ぎょうせい 13, 法 制 18, 石毛 12, 礒崎 06]）。そのため, 契約書, 約款, 定 款, 特許文書, 判決文といった広義の法令文書において も，法制執務規則に準じて法令用語が使用されることが 多い。しかし，法制執務の技術を修得するためには多大 の労力を要するうえ，経済活動の多様化などに伴う法令 


\begin{tabular}{|c|c|}
\hline 著作者 著作物を創作する者 & [1] \\
\hline 著作権法（昭和 40 年法律第 48 号）第 2 条第 1 項第 & 刀一部 \\
\hline $\begin{array}{l}\text { レコード 蓄音機用音盤、録音テープその他の } \\
\text { 固定したもの }\end{array}$ & \\
\hline 著作権法（昭和 40 年法律第 48 号）第 2 条第 1 項第 & 刀一部 \\
\hline 著作物 思想又は感情を創作的に表現したもの & [3] \\
\hline
\end{tabular}

著作権法（昭和 40 年法律第 48 号）第 2 条第 1 項第 1 号の一部

図 1 法令用語「者」「物」「もの」を含む句

文書作成業務の増加によって，法令用語の校正にかかる 負担は増大している。

そこで，本論文では，法令文に出現する法令用語を自 動校正する手法を提案する．その際，互いに類似する法 令用語の組（以降，法令用語集合という）を選択肢と考え ることにより，法令用語校正問題を特殊な選択肢付き穴 埋め問題とみなす。選択肢付き穴埋め問題において, 解 答の予測には一般的に言語モデル（たとえば，[Gubbins 13, Katz 87, Mikolov 13, Mnih 13, 森 15, Woods 16]）が 用いられる。一方，本論文では，各法令用語集合に特化 したランダムフォレスト分類器を用いて最適な法令用語 を提示する，なお，本研究では，データの質，量，およ び入手可能性の観点から, 法令のうち法律および政令の テキストのみを扱う。

すなわち本論文は，法令用語校正問題を選択肢付き穴 埋め問題として形式的に定義したうえで，ランダムフォ レストを用いた法令用語校正手法を提案し，その有効性 を検証することによって，法令用語校正タスクの発展に 貢献する。

本論文の構成は次のとおりである，2 章では，法制執 務規則に定義されている法令用語集合について説明する. 3 章では，関連研究を紹介する．4 章では，法令用語校正 問題を定義し，本手法を説明する． 5 章では，本手法の 評価実験について述べ，6章で実験結果について議論す る.最後に，7章で本論文を総括する.

\section{2. 法令用語集合}

法制執務規則は法令文特有の意味・用法を持つ法令用 語を定義しており，特に，類似した法令用語の各組に対 してそれぞれの使い分け方を示している．法令を起草す る際には，この定義に基づいて法令用語を使用しなけれ ばならず，定義に反して法令用語を使用すると，法令文 の意図や解釈が異なるものになる。

法令用語は名詞とは限らず，動詞，形容詞，副詞など の場合もある.また，一つの法令用語が複数の単語から 構成されている場合，すなわち複単語表現である場合も
前条の著作隣接権の制限に関する規定（同条第七項及び 第八項の規定を除く。）は、実演家人格権に影響を及ぼ すものと解釈してはならない。

著作権法（昭和 40 年法律第 48 号）第 102 条の 2 第 1 項

指定管理団体は、補償金関係業務を開始しようとすると きは、補償金関係業務の執行に関する規程を定め、文化 庁長官に届け出なければならない。これを変更しようと するときも、同様とする。

著作権法（昭和 40 年法律第 48 号）第 104 条の 7 第 1 項

図 2 法令用語「規定」,「規程」を含む法令文

ある，以下に，法制執務規則を記した解説書 [ぎょうせ い13, 法制 18, 石毛 12, 礒崎 06] に定義されている法令 用語集合の例を示す。

\section{$2 \cdot 1$ 「規定」と「規程」}

「規定」は個々の条項を表す一方,「規程」はある目的 のために定められた一連の条項の総体を表す。「規定」と 「規程」の使い分けの例を図 2 に示す.

\section{$2 \cdot 2 「$ 直ちに」と「速やかに」と「遅滞なく」}

「直ちに」,「速やかに」,「遅滞なく」は，どれも時間的 に遅れてはならないことを表現するために用いるが，こ の順で，より厳しい時間的制約を課していることを示す. それぞれの用法に着目すると, 通例では, 「直ちに」と「遅 滞なく」は遅延によって罰則が生じる場合に用いられる 一方，「速やかに」はあくまで訓示的な表現であって罰則 は与えない場合に用いられる. また，意味に着目すると， 「直ちに」と「速やかに」は一切の遅延を認めない意味を 含んでいる一方,「遅滞なく」は正当または合理的な遅延 は許されるという意味を含んでいる。「直ちに」,「速やか に」,「遅帯なく」の使い分けの例を図 3 に示す.

\section{$2 \cdot 3$ 前項の場合において」と「前項に規定する場合に おいて」}

「前項の場合において」と「前項に規定する場合にお いて」は，どちらも直前の項の内容を補足するときに用 いるが，前者は項全体を言及する際に，後者は項で規定 されている条件のみを言及する際に用いる．両者の使い 分けの例を図 4 に示す.

\section{3. 関 連 研 究}

本論文では，法令用語校正問題を選択肢付き穴埋め問 題に還元する. そこで，3·1 節において，この問題を説明 する. 次に，選択肢付き穴埋め問題の解決に対してょく 使用される言語モデルに関して，3·2 節において紹介す 
交通事故があつたときは、当該交通事故に係る車両等の 運転者その他の乗務員（以下この節において「運転者等」 という。）は、直ちに車両等の運転を停止して、負傷者 を救護し、道路における危険を防止する等必要な措置を 講じなければならない。

道路交通法（昭和 35 年法律第 105 号）第 72 条第 1 項の一部

高齢運転者等標章の交付を受けた者は、普通自動車対応 免許が取り消され、又は失効したとき、第一項第三号に 規定する事由がなくなつたときその他内閣府令で定める 事由が生じたときは、速やかに、当該高齢運転者等標章 をその者の住所地を管轄する公安委員会に返納しなけれ ばならない。

道路交通法（昭和 35 年法律第 105 号）第 45 条の 2 第 4 項

第二百十六条（源泉徵収に係る所得税の納期の特例）の 承認を受けた者は、その承認に係る事務所等において給 与等の支払を受ける者が常時十人未満でなくなつた場合 には、遅滞なく、その旨その他財務省令で定める事項を 記載した届出書を当該事務所等の所在地の所轄税務署長 に提出しなければならない。

[8]

所得税法（昭和 40 年法律第 33 号）第 218 条第 1 項の一部

図 3 法令用語「直ちに」,「速やかに」,「遅滞なく」を含む法令文

る. 最後に, 本手法が法令用語校正問題を解くために使 用するランダムフォレスト [Breiman 01] について，3·3 節において説明する.

\section{$3 \cdot 1$ 選択肢付き単語穴埋め問題}

一般的な選択肢付き穴埋め問題では，穴あき文と選択 肢が与えられる。ただし，穴あき文には空白が 1 箇所だ け存在し, 選択肢にはその空白を埋めるための単語（単 語列である場合もある）が一つ含まれる，以下に典型的 な問題の例を示す.

$\mathrm{He}$ is at the scoreboard.
(A) look
(B) looks
(C) looking
(D) looked

ここで, が空白である，解答者は，与えられた選 択肢から，この空白を埋めるために最も適切な単語（こ の場合，(C)）を選択する.

与えられる選択肢は個々の問題や出題意図によって大 きく異なることがある．たとえば，動詞の意味理解を問 うために，同じ文に対して次の選択肢を与えることが考 えられる。

He is at the scoreboard.
(A) looking
(B) watching
(C) seeing

さらに，選択肢に正解となる単語（列）が一つ含まれ
軽車両は、前条第一項の規定にかかわらず、著しく歩行 者の通行を妨げることとなる場合を除き、道路の左側部 分に設けられた路側帯（軽車両の通行を禁止することを 表示する道路標示によつて区画されたものを除く。）を 通行することができる。

2 前項の場合において、軽車両は、歩行者の通行を妨 げないような速度と方法で進行しなければならない。[10]

道路交通法 (昭和 35 年法律第 105 号) 第 17 条の 2 第 1 項・第 2 項

前二条の規定は、募集株式を引き受けようとする者がそ の総数の引受けを行う契約を締結する場合には、適用し ない。

2 前項に規定する場合において、募集株式が譲渡制限 株式であるときは、株式会社は、株主総会（取締役会設 置会社にあっては、取締役会）の決議によって、同項の 契約の承認を受けなければならない。ただし、定款に別 段の定めがある場合は、この限りでない。

会社法（平成 17 年法律第 86 号）第 205 条第 1 項 ·第 2 項

図 4 法令用語「前項の場合において」と「前項に規定する場合に おいて」を含む法令文

ていれば，他の選択肢の数は任意でよい，たとえば，次 のような選択肢であっても，一般的な選択肢付き穴埋め 問題の枠組みから外れない.
(A) looking
(B) he
(C) likes
(D) soccer
(E) very much

そのため，一般的な選択肢付き穴埋め問題を解くための 手法は，あらゆる選択肢に対処する必要がある。

\section{$3 \cdot 2$ 言語 モ デル}

前項で述べた選択肢付き穴埋め問題を解くために適し たツールの一つが言語モデルである，一般に，言語モデ ルは, 単語列 $W=w_{1} w_{2} \ldots w_{|W|}$ に対して, その単語列 が生成される確率，すなわち単語列のもっともらしさを 割り当てる.ここで， $W$ を構成する各単語 $w_{i}$ は，言語モ デルが定義している語彙から選択される。そのため，穴 あき文や選択肢の中の各単語が語彙に含まれている限り， 言語モデルはどのような問題の文に対しても確率を付与 できる.

言語モデルの性能を評価するために，Zweig と Burges は選択肢付き穴埋め問題の問題セットである MSR Sentence Completion Challenge Data を作成した [Zweig 11]. さまざまな研究において, この問題セットを用いた言語モ デルの評価がなされている.はじめに, Zweig と Burges は，自身が作成した問題セットを用いて $n$-gram 言語モ デルを評価した [Zweig 11]. n-gram 言語モデルは最もシ ンプルな言語モデルの一つであり，長さ $n-1$ の単語列 からその単語列の次に来る単語を予測する，以降，言語 
モデルによって予測される単語を予測単語という.

一方，この問題セットで評価された最近の言語モデル の多くはニューラルネットワークを用いて構築されてい る. 以降，このような言語モデルをニューラル言語モデ ルという. ニューラル言語モデルは, 個々の単語や単語 列をベクトルで扱うことによって, $n$-gram 言語モデルが 抱えていた次元の呪い [Bengio 03] を解決した.

たとえば, Mikolov らは二つのニューラル言語モデル CBOW (Continuous Bag-of-Words) と Skip-gram を提案 した [Mikolov 13]. CBOW は予測単語の前後にある単語 を入力し，それらから一つのベクトルを生成し，そのべ クトルを用いて予測単語の確率分布を生成するモデルで ある. 一方, Skip-gram は予測単語を入力し, その単語 をべクトルに変換し，隣接する単語の確率分布を生成す る. Mnih と Kavukcuoglu は vector Log-bilinear model (vLBL) とivLBL を提案した [Mnih 13]. これらは，予 測単語から生成したベクトルと，予測単語の前後 $n$ 単語 から生成した一つのベクトルとの類似度を用いて，予測 単語を選択する。森らは, vLBL を改良したニューラル 言語モデル vLBL(c) と vLBL+vLBL(c) を提案した [森 15]. $\operatorname{vLBL}(\mathrm{c})$ は, 予測単語の前後にある単語からべクト ルを生成する際，同じ単語でも予測単語との相対位置に よって異なるべクトルを使用する．vLBL+vLBL(c) は， vLBL(c) と前述の vLBL を組み合わせたモデルである. また, Mirowski と Vlachos は文の構文情報を利用した言 語モデルを提案した [Mirowski 15]. この言語モデルは RNN (Recurrent Neural Network) [Elman 03, Jordan 86] で構築されている.

多くの研究でニューラル言語モデルが提案されている 一方，ニューラルネットワークを用いない言語モデルも 提案されている。たとえば, Gubbins とVlachos は, $n$ gram 言語モデルに似た言語モデルを提案した [Gubbins 13].この言語モデルでは, $n$-gram の代わりに係り受け 木を用いて単語を予測する。 Woods は自己相互情報量に 基づいた言語モデルを提案した [Woods 16]. この言語モ デルでは，文脈，依存関係，キーワードの三つの素性を 組み合わせた素性セットを用いる.

\section{$3 \cdot 3$ ランダムフォレスト}

ランダムフォレスト [Breiman 01] はアンサンブル機械 学習手法の一つである。本論文では，ランダムフォレス トを多クラス分類器として用いる. 図 5 にランダムフォ レストの学習プロセスと予測プロセスを示す.

ランダムフォレストは，学習プロセスにおいて，与えら れた訓練データから複数の決定木を構築することによっ てモデルを生成する。また，予測プロセスにおいては， 各々の決定木に当該事例を入力し，それぞれの決定木が 出力した結果を総合して最終的な結果を出力する.

ここで，決定木は，if-then ルールを表現した二分木で あり，図 5 の中央部に記載した各々の木に対応する. 決定

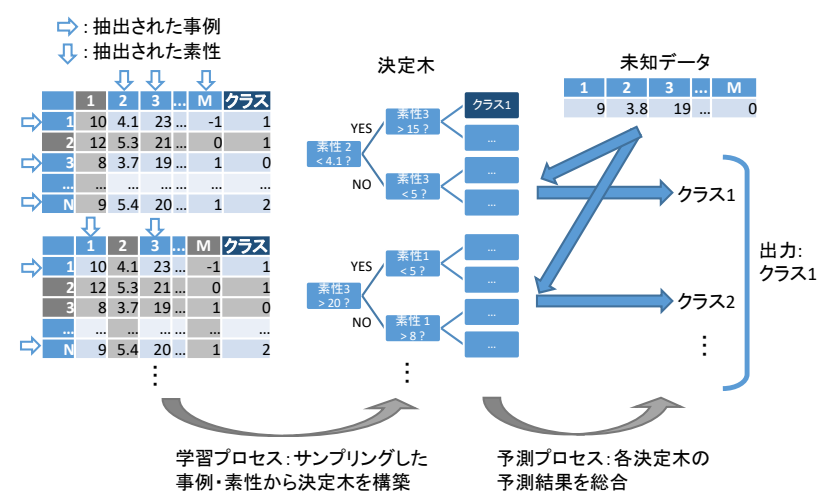

図 5 ランダムフォレストの処理手順

木において, 内部ノードは一つの条件を表し, 訓練デー タをより明確に分離するような素性と值が選択される. ノードを始点とする二つの辺のうち，一つは条件を満た したことを表し，もう一つは条件を満たさなかったこと を表す。決定木の葉ノードは，分類問題においてはどれ か一つのクラスを表す。

ランダムフォレストの最大の特徵は, ランダムに抽出 した素性と事例を用いて各々の決定木を構築することに ある。具体的には, 与えられた訓練データから重複を許 して事例をサンプリング（ブートストラップ・サンプリン グ）し，さらに，重複しないように素性をサンプリングす る.これによって, Adaboost [Freund 97] などの他のアン サンブル機械学習手法と同等以上の性能が得られること, 外れ值やノイズに対して頑健であること，容易に処理を 並列化できることなどの恩恵が得られる [Breiman 01]. また，事例をランダムにサンプリングするため, 各々の 決定木に対して, 決定木の構築に使われない (out-of-bag) 事例が発生する。この out-of-bag 事例を用い, 各々の素 性の重要度を算出することができる。ここで， $n$ 番目の 素性の重要度を算出する手順を以下に示す.

(1) 事例をランダムにサンプリングし, $m$ 個目の決定 木 $T_{m}$ を構築する。

(2) $T_{m}$ における out-of-bag 事例の集合 $E_{m, 0}$ を取得す る.

(3) $E_{m, 0}$ の各事例における $n$ 番目の素性をシャッフル した（事例間で素性をランダムに交換した）事例の 集合 $E_{m, n}$ を作成する.

(4) $T_{m}$ を用い, $E_{m, 0}$ の各事例のクラス $C_{m, 0}$ と $E_{m, n}$ の 各事例のクラス $C_{m, n}$ をそれぞれ予測する.

(5) $C_{m, 0}$ と $C_{m, n}$ における予測の誤り率 $a_{m, 0}$ と $a_{m, n}$ を それぞれ求め, 素性のシャッフルによる誤り率の増 加量を計算する.

（6）以上の操作をそれぞれの決定木に対して実施し, 誤り率の増加量の合算値 $x_{n}$ を得る.

（7） $x_{n}$ が大きい場合，素性のシャッフルによって正確 に予測できなくなることを表すため, $n$ 番目の素性 の重要度は高いとみなす. 


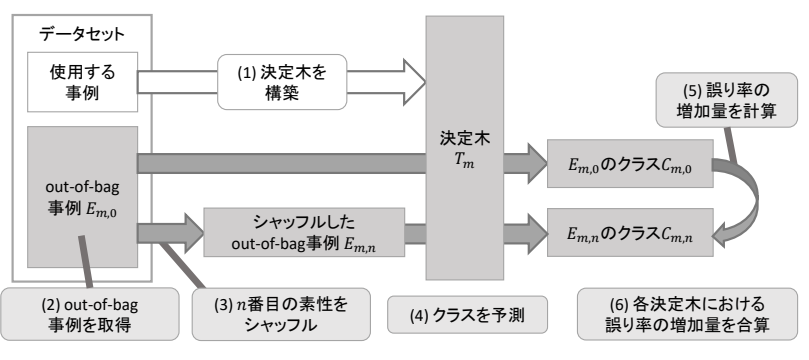

図 6 素性の重要度を算出する手順

(1) から (6) までの手順を図 6 に示す.

\section{4. 提 案 手 法}

本章では，ランダムフォレストを用いた法令用語校正 手法を説明する. $4 \cdot 1$ 節では, 法令用語校正問題を定義 し，この問題を解くための一般的なアルゴリズムを提示 する. 4.2 節では, この問題が特殊な選択肢付き穴埋め 問題とみなせることを示し, 一般的な選択肢付き穴埋め 問題と比較する. 4.3 節では, この問題に対してランダム フォレストを適用する方法について述ベ，ランダムフォ レストを用いることの利点について議論する。

\section{$4 \cdot 1$ 定義}

本論文では，法令用語校正問題を次のように定義する.

- 法令文 $W=w_{1} w_{2} \cdots w_{|W|}$ と法令用語集合 $T \subseteq V^{+}$ が与えられる。ここで, $V$ は語彙であり, $W$ 中の各 単語 $w_{i}$ は $w_{i} \in V$ である. また, $V^{+}$は $V$ のクリー ネ閉包である. そのため, 単語だけでなく複単語表 現も法令用語 $t \in T$ として扱える.

-Wにおいて用いられている法令用語 $t=w_{i} w_{i+1} \ldots w_{j}$ の尤度を算出する.

•もし, 他の法令用語 $\hat{t} \in T(\hat{t} \neq t)$ の尤度が $t$ の尤度 より大きい場合, $t$ を $\hat{t}$ に修正すべきである旨を出力 する.

本問題では，与えられた法令文から法令用語を検出し，誤 用されていると思われるものに対して修正案を提示する.

次に，この問題を解くための一般的なアルゴリズムを Algorithm 1 に提示する. Algorithm 1 において, $W_{l}, W_{r}$ はそれぞれ法令用語 $t$ の左側, 右側の単語列である. また, $\operatorname{score}\left(W_{l}, t, W_{r}\right)$ は $t$ の尤度を計算する関数である.

たとえば，次の法令文 $W$ と法令用語集合 $T$ について 考える.

$$
\begin{aligned}
& W=\text { 著作物_を_創作する_もの_の_保護 } \\
& \begin{array}{lllll}
1 & 2 & 3 & 4 & 5
\end{array} \\
& T=\{\text { 者, 物, もの }\} \text {. }
\end{aligned}
$$

ここで, - は単語の区切りである.このとき, $W$ から法 令用語「もの」 $\left(=w_{4}\right)$ を検出し, $W_{l}$ と $W_{r}$ をそれぞれ $W_{l}=$ 「著作物_を_創作する」, $W_{r}=「$ 「_保護」とおく．次

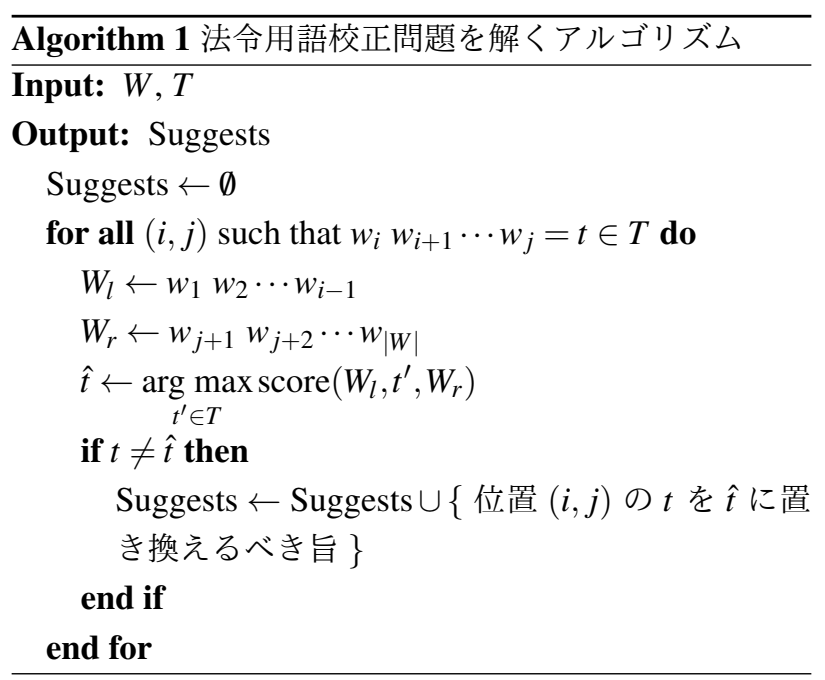

に， $w_{4}$ を用いたとき，および $w_{4}$ を $T$ 中の他の法令用語 に置き換えたときの尤度を以下の式によって計算する.

score (著作物_を_創作する，者，の_保護)， score (著作物_を_創作する，物，の_保護)，

score (著作物_を_創作する,もの,の_保護).

それぞれの式は，具体的には単語列「著作物_を_創作す る_者_の_保護」，「著作物_を_創作する_物_の_保護」，「著 作物_を_創作する_もの_の_保護」の尤度を計算する。こ の場合,「著作物_を_創作する_者_の_保護」の尤度を最も 高く評価し，「もの」を「者」に修正する旨の提案を出力 するべきである.

\section{$4 \cdot 2$ 本問題の特徵付け}

本論文では，次のアイデアを導入することによって， $4 \cdot 1$ 節で定義した問題を選択肢付き単語穴埋め問題と捉 える.

- $W_{l}$ $W_{r}$ を穴あき文とみなす。ここで， は

空白であり, $W_{l}$ と $W_{r}$ は Algorithm 1 で定義した単 語列である.

・ $T$ を選択肢とみなし，ある $t \in T$ が穴あき文の空白 を適切に埋めると考える。

しかし，この問題は，一般的な選択肢付き穴埋め問題 と二つ異なる点がある。一つ目は，一組の選択肢，すなわ ち法令用語集合が多数の穴あき文と対応関係にある点で ある．たとえば，法令用語集合 $T=\{$ 者,物,もの $\}$ 中の 各法令用語は，現行法令から取得した約 4,700 万語の法 令文コーパスにおいて数万回から数十万回出現する．つ まり，一つの法令用語集合に対して数十万個の問題文を 作成することができる。一方，一般的な選択肢付き穴埋 め問題において，穴あき文は，空白の場所や出題意図に よってそれぞれ異なる選択肢を持つことができる．その ため，前述のように，一組の選択肢が数十万個の穴あき 文と対応していると考えることは現実的ではない。

二つ目は，法制執務規則に定義されている限られた数 
の法令用語集合のみを選択肢として考慮すればよい点で ある．たとえば，法令用語集合 $\{$ 者，直ちに\}は，名詞 「者」と副詞「直ちに」から構成されており，これらを混 同することは限りなく稀である．そのため，この法令用 語集合を考慮する必要性は極めて低い。一方，一般的な 選択肢付き穴埋め問題では，あらゆる選択肢が許容され ている。 そのため，一般的な選択肢付き穴埋め問題を解 く際には，上述のような無意味な選択肢にも対応できな ければならない。

\section{$4 \cdot 3$ ランダムフォレストの使用}

前節で述べた特性を踏まえ，本論文ではランダムフォ レスト [Breiman 01] を本手法に対して適用する．具体的 には，次式のように，スコア関数 $\operatorname{score}\left(W_{l}, t, W_{r}\right)$ として ランダムフォレスト分類器を用い，その素性として $t$ の 前後 $N$ 単語を用いる.

$$
\operatorname{score}\left(W_{l}, t, W_{r}\right)
$$

$=\sum_{d \in D} P_{d}\left(t \mid w_{l}^{\left|W_{l}\right|-N+1}, \ldots, w_{l}^{\left|W_{l}\right|-1}, w_{l}^{\left|W_{l}\right|}, w_{r}^{1}, w_{r}^{2}, \ldots, w_{r}^{N}\right)$.

ここで， $D$ は決定木の集合， $d$ は個々の決定木, $P_{d}\left(t \mid w_{1}, w_{2}, \ldots, w_{N}\right)$ は $d$ が単語列 $w_{1} w_{2} \ldots w_{N}$ を素性と して法令用語 $t$ を選択する確率（実際には 0 または 1 ) である. $w_{l}^{i}$ と $w_{r}^{i}$ は，それぞれ $W_{l}$ と $W_{r}$ の $i$ 番目の単語 である．以降， $N$ をウィンドウサイズという．たとえば, $N=2$ のとき，式 (3) のスコア関数は次のように計算で きる.

score(著作物_を_創作する,者,の_保護)

$$
=\sum_{d \in D} P_{d}(\text { 者 } \mid \text { を,創作する,の,保護). }
$$

本手法はそれぞれの法令用語集合ごとに一つのランダ ムフォレスト分類器を構築する.

本手法では，以下に述べる二つの理由により，3.2 節 で述ベたニューラル言語モデルではなく，ランダムフォ レストを本問題に適用する.

（1）各々の法令用語集合に合わせて各ランダムフォレ スト分類器のパラメータを設定できるため.

特に，法令用語集合ごとに異なるウィンドウサイズを 設定できることは有益である．たとえば，「直ちに」， 「速やかに」,「遅滞なく」の使い分けは，一般に文全 体から判断する必要がある。そのため, 広いウィン ドウサイズを使用することが望ましいと考えられる. 一方，言語モデルは単一のデータセットから学習す るため, どのような法令用語集合の予測に対しても 同じパラメータを用いなければならない。

（2）ランダムフォレストは，法令用語が複単語表現で あっても容易に対処できるため.

ランダムフォレストは，単語数によらず法令用語を 単一のクラスとして扱える。一方，3.2 節で述べた

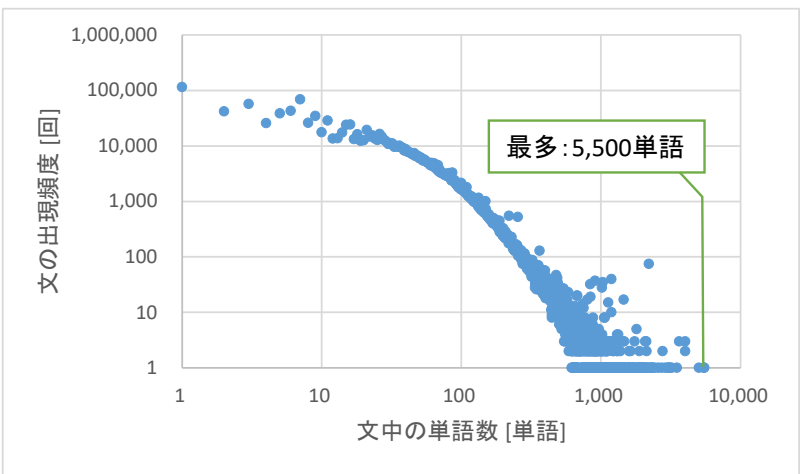

図 7 法令文を構成する単語の数の分布

CBOW や vLBL などの言語モデルは，与えられた 文脈から一つの単語を予測するように設計されてい る.そのため, これらの言語モデルで複単語表現の 法令用語を扱うためには, 複単語表現を一単語に結 合するなどの前処理が必要になる.

\section{5. 実験}

本手法の有効性を検証するために，法令文に出現する 法令用語に対する予測実験を行った。

\section{$5 \cdot 1$ 概 要}

総務省が提供している e-Gov 法令検索 ${ }^{* 1}$ から現行の法 律と政令の XML 文書データ 3,983 件を 2018 年 5 月 18 日に取得し，コーパスを作成した。具体的には，XML 文 書データにおいて Sentence タグで囲まれているテキスト を一文とみなして抽出し，MeCab (v0.996) *2を用いて形 態素解析を施した ${ }^{* 3}$. 形態素解析の辞書には IPA 辞書を 用いた。コーパスの文数は $1,223,084$ 文，延べ単語数は 46,919,612 単語, 異なり単語数は 41,470 単語である. 法 令文を構成する単語の数の分布を図 7 に示す．単語数の 平均値は 37.0 単語, 中央值は 18 単語である. 図 7 にお いて, 単語数が 1 の法令文が多く存在するが，そのほと んどは，号で列挙されている単語や条項を削除したこと を示す「削除」に由来する。

法令用語集合は, 法制執務の解説書 [ぎょうせい 13 , 法 制 18, 石毛 12, 礒崎 06] を参考に 27 個を定義した。法令 用語集合の一覧を付録 $\mathrm{A}$ に記載する。付録 $\mathrm{A}$ に記載し ている法令用語の出現頻度は, 後述する複単語表現の単 一単語化を施した後の数である。なお，動詞および形容 詞の法令用語において，付録 $\mathrm{A}$ に記載した法令用語と表 層形が一致するものを予測の対象とした。法令文に含ま

*1 http://elaws.e-gov.go.jp/

$* 2$ http://taku910.github.io/mecab/

*3 法令文において,「事由がなくなつたとき」など「つ」が「つ」 と書かれる場合がある。このとき，この表現を䛊って形態素解 析する可能性があるが, 今回の実験においては, 品詞や読みな どの形態素に関する素性を使用していないため，結果に大きな 影響が生じないと判断し，原文の表現のままとした。 


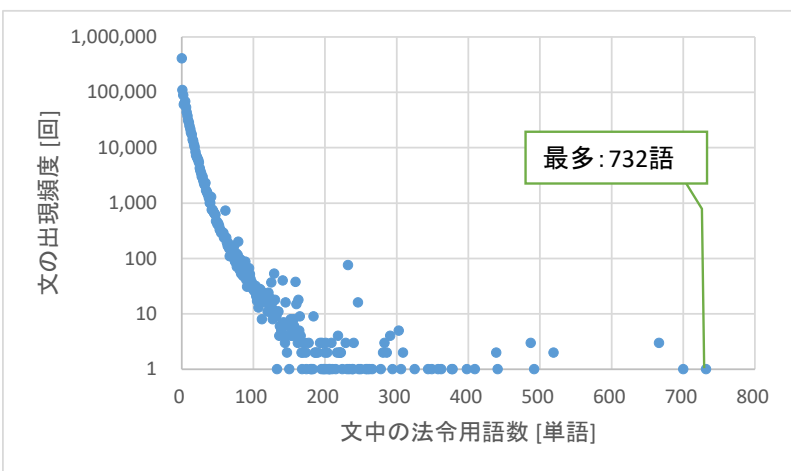

図 8 法令文に含まれる法令用語の数の分布

目次の改正規定（「(第一条)」を「(第一条・第一条の 二)」に、「第一条の二」を「第一条の三」に改める部分 に限る。、第一条の三を第一条の四とし、第一条の二を 第一条の三とする改正規定、…第十七条第二項、第三 項及び第五項、第十八条第二項、第二十二条、第三十一 条、第三十八条並びに第四十条第一項及び第三項の規定

図 9 法令用語を最も多く含む文

れる法令用語の数の分布を図 8 に示す. 法令用語数の平 均值は 5.99 単語, 中央值は 3 単語である. 最も法令用語 数の多い法令文は, 租税特別措置法施行令の一部を改正 する政令（平成 19 年政令第 92 号）による租税特別措置 法施行令（昭和 32 年政令第 43 号）の改正に伴う附則第 1 条第 6 号の文であり, 5,034 単語から構成され, 732 法 令用語を含む. 図 9 にその一部を示す.

提案手法と比較した手法は, CBOW [Mikolov 13], Skipgram [Mikolov 13], vLBL [Mnih 13], vLBL(c) [森 15], vLBL+vLBL(c) [森 15] と $n$-gram である. ニューラル言語 モデル (CBOW, Skip-gram, vLBL, vLBL(c) と vLBL+vLBL(c))については，それぞれの文献に従い，ウ ィンドウサイズを 5 に設定した。そのほかのパラメータ として, 単語ベクトルの次元数を 200 に, エポック数を 5 に, ミニバッチサイズを 512 に, 負例サンプリングの 数を 10 (Skip-gram と vLBL 系のみ) に設定した. 最適 化関数は Adam [Kingma 15] を用いた。実装, 訓練, テ ストは Chainer ${ }^{* 4}$ (v.1.7.0) を用いた. また, $n$-gram とし て, Zweig と Burges [Zweig 11]に従い, Katz のバック オフ [Katz 87] を適用した trigram と 4-gram を実装し, 訓練，テストを実施した。

提案手法については，(1) ニューラル言語モデルと同様 にウィンドウサイズを 5 に固定する場合と，(2) それぞれ の法令用語集合ごとに最適なウィンドウサイズを $\{2,5$, $10,15\}$ から選択する場合の二つを設定する. 後者のウィ ンドウサイズは， 5 分割交差検証によって最適な值を選 択した. 以降, 前者の手法を RF（固定）, 後者の手法を

*4 https://chainer.org/
RF（可変）という. 両方の手法において, 決定木の構築 基準としてジニ係数を用い，それぞれの法令用語集合ご とに最適な決定木の数 $\{10,50,100,500\}$ と決定木の深 さ $\{10,100,1000$, 無制限 $\}$ を 5 分割交差検証によって求 めた。 なお，法令用語集合 ID20（\{の，に規定する，の規 定による \}) については, その出現頻度が特に多く, 計 算コストを抑えるために, ランダムに抽出した $1,000,000$ 件を用いてランダムフォレストを構築した。実装, 訓練, テストは Scikit-learn (v.0.19.1) によって実施した.

ニューラル言語モデルや $n$-gram 言語モデルは単一の 単語を予測する. そのため, 複単語表現である法令用語 （例：「前項_の_場合_において」）は最長一致に基づいて 事前に結合し（例：「前項の場合において」），単一の 単語とした。この処理を施した後のコーパスの延べ語数 は 45,213,528 語となった。また，計算コストの削減のた めに, 出現回数が 5 回以下の単語は，すべて未知語を表 すトークンに変換した．訓練と予測において，入力単語 列の長さがウィンドウサイズに足りない場合, トークン $<\mathrm{EOS}>$ でパディングした.

訓練データとテストデータは，コーパスに含まれる法 律と政令合計 3,983 件を文書単位で分割することによっ て作成した。訓練データは合計 3,784 件の法律と政令か ら構成され，1,185,424 文，43,655,941 単語からなる.一 方, テストデータは合計 199 件の法律と政令から構成さ れ，37,660 文， 1,557,587 単語からなる. テストデータ に出現する法令用語の数は延べ 251,085 語である.

評価指標として, 各々の法令用語に対する正解率のマ イクロ平均 $\left(a c c_{\text {micro }}\right)$, 法令用語集合単位のマクロ平均 $\left(a c c_{\text {macro-s }}\right)$, 法令用語単位のマクロ平均 $\left(a c c_{\text {macro-w }}\right)$ を 用いた。

\section{$5 \cdot 2$ 結果}

表 1 に実験の結果を示す. ベースラインとして, 最尤 法に基づいて法令用語を選択したときの正解率のマイク ロ平均とマクロ平均を併記する.ここで, 最尤法は, す心゙ ての問題に対して出現頻度の最も高い法令用語を選択す る方法である. 表 1 において,*は, RF (可変) と比べて 正解率に有意な $(p<0.05)$ 差があることを表す。また, 太字は, 各評価指標において值が最も高いことを表す.

$\mathrm{RF}$ (可変) がすべての評価基準において最も高い正解 率を達成し, $a c c_{\text {micro }}$ と $a c c_{\text {macro-w }}$ についてはすべての 手法と比べて， $a c c_{\text {macro-s }}$ については RF（固定）を除く すべての手法と比べて有意差が見られた。

提案手法による予測の成功例を図 10 に示す。図 10 の 文の下線部に対して「者」,「物」,「もの」から適切な法令 用語を選択する. また, 波括弧内の文字列は, 分類器に 入力される単語を表す. RF（可変）および RF（固定）は 「者」を選択し, vLBL+vLBL(c) は「もの」を選択した. この例では, 下線部の直前にある「同項に規定する者」と その直後にある「その他の 」が並列していると考 
表 1 各手法における法令用語予測の性能

\begin{tabular}{l|ccc}
\hline 手法 & $a c c_{\text {micro }}$ & $a c c_{\text {macro-s }}$ & $a c c_{\text {macro-w }}$ \\
\hline \hline RF (固定) & $95.20 \% *$ & $92.86 \%$ & $83.57 \% *$ \\
RF (可変) & $\mathbf{9 5 . 3 7 \%}$ & $\mathbf{9 3 . 2 2 \%}$ & $\mathbf{8 4 . 6 8 \%}$ \\
CBOW & $88.82 \% *$ & $84.65 \% *$ & $74.94 \% *$ \\
Skip-gram & $75.42 \% *$ & $63.07 \% *$ & $65.68 \% *$ \\
vLBL & $80.23 \% *$ & $75.46 \% *$ & $74.17 \% *$ \\
vLBL(c) & $91.38 \% *$ & $86.32 \% *$ & $80.67 \% *$ \\
vLBL+vLBL(c) & $90.95 \% *$ & $85.62 \% *$ & $81.12 \% *$ \\
trigram & $87.12 \% *$ & $85.81 \% *$ & $69.36 \% *$ \\
4-gram & $88.81 \% *$ & $87.83 \% *$ & $72.58 \% *$ \\
\hline 最尤法 & $78.61 \% *$ & $62.49 \% *$ & $38.81 \% *$ \\
\hline
\end{tabular}

…期間 内に同 $\{$ 項に規定する者とその他の

とが共同して\} 作成した文書...

小笠原諸島の復帰に伴う大蔵省関係法令の適用の

暫定措置等に関する政令（昭和 43 年政令第 202 号)

第 11 条第 2 項の一部

図 10 提案手法が成功した事例

えられるため,「者」を選択すべきである，なお，RF（可 変）は，この例に対応する法令用語集合 ID3（\{者，物， もの\}）に対して，ウィンドウサイズ 5 を選択した。そ のため, $\mathrm{RF}$ (可変), $\mathrm{RF}$ (固定), $\mathrm{vLBL}+\mathrm{vLBL}(\mathrm{c})$ のい ずれの手法においても，同一の文脈から法令用語を予測 した.

次に, 提案手法による予測の失敗例を図 11 に示す. 図 11 の文の下線部に対して「又は」,「若しくは」から 適切な法令用語を選択する，なお，角括弧内の文字列は $\mathrm{RF}$ (可変) に入力された単語を, 波括弧内の文字列は RF (固定) および各種ニューラル言語モデルに入力される単 語をそれぞれ表す．RF（可変）およびRF（固定）は「又 は」を選択し，vLBL+vLBL(c) は「若しくは」を選択し た．法令文において，「又は」と「若しくは」は，並列構 造の階層を明示するために使い分けられる．具体的には， $\Gamma($ 三年以下の懲役若しくは百万円以下の罰金) 又はその 両方」のように,「又は」は最も大きな並列構造に対して 用いられ，「若しくは」はそれ以外の並列構造に対して用 いられる。ここで，図 11 の文は,「その出版物を国立国会

… 但し、発行者 [がその出版物を\{国立国会 図書館に寄贈遺贈したとき、\} 又は館長が 特別の]事由があると認めたときは、この限りで ない。

国立国会図書館法（昭和 23 年法律第 5 号） 第 25 条第 1 項の一部
表 2 ウィンドウサイズと法令用語集合

\begin{tabular}{r|l}
\hline WS & \multicolumn{1}{|c}{ 法令用語集合の ID } \\
\hline \hline 2 & $1,6,8,13,15,19$ \\
5 & $2,3,4,5,7,9,12,18,20,22,25$ \\
10 & $11,14,17,21,23,24$ \\
15 & $10,16,26,27$ \\
\hline
\end{tabular}

図書館に（寄贈 or 遺贈）したとき」と「館長が特別の事 由があると認めたとき」の並列と考えることが自然であ る. そのため，当該箇所には「又は」ではなく「若しく は」を用いるべきである.すなわち, RF（可変）や RF （固定）の予測は誤っている.

\section{6. 考 察}

本章では，ランダムフォレストによる法令用語校正手 法の特徵と有効性をより詳細に明らかにするために, 実 験結果について考察する. $6 \cdot 1$ 節では, ウィンドウサイ ズ選択の効果に関して議論する. 6.2 節では，ランダム フォレスト分類器を構築する過程で得られた素性の重要 度について分析する. 6.3 節では, 法令用語予測の難易 度に関わる要因について, 実験結果と照らし合わせて考 察する. 6.4 節では, 訓練データの不均衡性によって生 じた課題とその対策について議論する。

\section{$6 \cdot 1$ 可変長ウィンドウサイズの効果}

本節では, ウィンドウサイズを可変長にすることの効 果について議論する。具体的には, RF（可変）が選択し たウィンドウサイズの傾向，ランダムフォレストにおい てウィンドウサイズを可変長にした効果，RF（可変）の ウィンドウサイズ選択の最適性について明らかにする。 ま た, vLBL+vLBL(c)におけるウィンドウサイズと予測性 能の関係についても述べる.

はじめに, RF (可変) が選択したウィンドウサイズの 傾向を示す. $\mathrm{RF}$ (可変) は，5.1 節で定義した各々の法 令用語集合に対する分類器を構築する過程で，表 2 のと おりにウィンドウサイズを選択した。ここで，WS はウィ ンドウサイズを表し，法令用語集合の ID は付録 A に示 した法令用語集合の ID と対応している。表 2 より, RF (可変) はウィンドウサイズ 2 から 15 まですべて使用し たことがわかる. また，最も多く選択されたウィンドウ サイズは 5 であるため, RF（固定）においてウィンドウ サイズを 5 に設定することは合理的であったといえる.

次に，ランダムフォレストにおいてウィンドウサイズ を可変長にした効果を調査するために, RF (可変) が選 択したウィンドウサイズに基づいて法令用語集合を分類 し，それぞれのグループに対して，RF（可変）と RF（固 定）の正解率のマイクロ平均を求めた. 表 3 にその結果を 示す.ここで，*は RF（固定）と比べて有意 $(p<0.05)$ に差があったことを示す. ウィンドウサイズ 10 および

図 11 提案手法が失敗した事例 
表 $3 \mathrm{RF}$ （可変）が選択したウィンドウサイズに属する法令用語ご との正解率

\begin{tabular}{r|r|rc}
\hline $\mathrm{WS}$ & 法令用語の数 & $\mathrm{RF}$ (固定) & $\mathrm{RF}$ (可変) \\
\hline \hline 2 & 140,098 & $98.15 \%$ & $\mathbf{9 8 . 2 5 \%}$ \\
5 & 99,360 & $\mathbf{9 5 . 4 2 \%}$ & $95.40 \%$ \\
10 & 5,310 & $91.01 \%$ & $\mathbf{9 1 . 7 9 \% *}$ \\
15 & 6,317 & $93.51 \%$ & $\mathbf{9 6 . 1 5 \% *}$ \\
\hline
\end{tabular}

ウィンドウサイズ 15 において, RF（可変）は RF（固 定）と比べて有意に高い正解率を達成した。そのため, これらのウィンドウサイズに属する法令用語集合におい ては，広い文脈を使用することが有効であったといえる. また，ウィンドウサイズ 2 においても, 有意差は認めら れなかったものの, 0.10 ポイントの正解率向上が見られ た。一方, ウィンドウサイズ 5 においては, 0.02 ポイン 卜低い正解率となった。ただし，有意差は認められなかっ たため，ランダムな事例選択によるノイズが原因であっ たと思われる。

次に, RF (可変) によるウィンドウサイズ選択の最適 性を検証する．各々の法令用語集合について，RF（可変） が選択したウィンドウサイズとウィンドウサイズ $\{2,5$, $10,15\}$ のうち正解率が最も高くなるもの（すなわち, オ ラクルのウィンドウサイズ）とを比較した. その結果, 法令用語集合 27 個のうち, $81.4 \%(22 / 27)$ において, RF (可変）は, オラクルのウィンドウサイズと同一のウィン ドウサイズを選択した.オラクルのウィンドウサイズと 異なるウィンドウサイズを選択した法令用語集合につい て, ID10（\{前項に規定する場合において, 前項の場合 において $\}$, 総事例数 3,159 件）や ID21（\{直ちに, 速 やかに, 遅滞なく\}, 総事例数 11,192 件）など事例数の 少ないものが多い. そのため, 事例数を増やせば, ウィ ンドウサイズをより正確に選択できると考えられる。 ま た, 各々の法令用語集合について, RF（可変）が選択し たウィンドウサイズを用いる場合と, オラクルのウィンド ウサイズを用いる場合のそれぞれにおいて，テストデー タの正解率を計算した. その結果, RF (可変) が選択し たウィンドウサイズを用いた時の正解率が $95.37 \%$ あっ たのに対し，ウィンドウサイズをオラクルで与えた時の

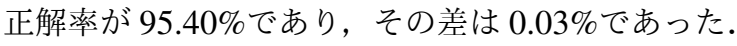

最後に, vLBL+vLBL(c)において, ウィンドウサイズ を変更したときの正解率を表 4 に示す. 表 4 には, 参考 として RF (固定) と RF (可変) の正解率を併記する.す なわち, マイクロ平均はウィンドウサイズを 10 にしたと きに最も高くなり，2 種類のマクロ平均はいずれもウィン ドウサイズを 15 にしたときに最高くなった。しかし， いずれの場合も, RF（固定）や RF（可変）の性能を下 回った。 また, ウィンドウサイズのオラクルを与えた場

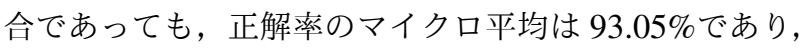
$\mathrm{RF}$ （固定）や RF（可変）のマイクロ平均を下回る.

\begin{tabular}{r|rrr}
\multicolumn{4}{c}{ ウィンドウサイズを変更したときの $\mathrm{vLBL}+\mathrm{vLBL}(\mathrm{c})$ の正解作 } \\
\hline $\mathrm{WS}$ & $a c c_{\text {micro }}$ & $a c c_{\text {macro-s }}$ & $a c c_{\text {macro-w }}$ \\
\hline 2 & $89.82 \%$ & $82.46 \%$ & $78.24 \%$ \\
5 & $90.95 \%$ & $85.62 \%$ & $81.12 \%$ \\
10 & $\mathbf{9 2 . 3 9 \%}$ & $84.64 \%$ & $81.28 \%$ \\
15 & $92.34 \%$ & $\mathbf{8 6 . 6 3 \%}$ & $\mathbf{8 1 . 5 0 \%}$ \\
\hline オラクル & $93.05 \%$ & $89.47 \%$ & $83.76 \%$ \\
\hline $\mathrm{RF}$ (固定) & $95.20 \%$ & $92.86 \%$ & $83.57 \%$ \\
$\mathrm{RF}$ (可変) & $95.37 \%$ & $93.22 \%$ & $84.68 \%$ \\
\hline
\end{tabular}

\section{$6 \cdot 2$ 重要度の分析}

$3 \cdot 3$ 節で述べたように, ランダムフォレスト分類器を 構築する過程で, 各々の素性が予測性能に寄与する度合 い（素性の重要度）が計算される．また，4·1 節で定義 したように，本問題における各々の素性は，対象の法令 用語から一定距離にある単語である。 そのため, ランダ ムフォレスト分類器が出力した素性の重要度から, 各々 の法令用語を予測するために重要となる単語の相対位置 の傾向，すなわち使用する文脈の傾向を調査することが できる。

各法令用語集合における素性の重要度を表 5 に示す. 相対位置は, 対象の法令用語の位置を 0 としたときの単 語の位置を表す．たとえば，相対位置 -1 は対象の法令用 語の直前に現れる単語に対応する。それぞれの法令用語 集合において，各相対位置に対応する重要度を足し合わ せると 1 になる.

表 5 から, 素性の重要度の傾向を次の 4 種類に類型化 する.

(1) 直近の単語に特に強く依存

ID1（\{規定, 規程 $\}) ， I D 2 （\{$ 場合，とき，時 $\} ）$, ID15（\{この限りでない, 妨げない $\}$ ）がこの類型に 属する. ID1について,「規定」は,「第三条の規定」 や「前号に掲げる規定」のように，言及する条項の 名称と併せて用いられやすいため，直前に「の」な どの助詞や「掲げる」などの動詞が出現しやすい．実 際に，訓練データにおいて，「規定」の直前の単語の 78.0\%（302,191 語）が「の」であった。一方，「規 程」は「業務規程」や「事務規程」のように，規程 の対象の名称と併せて用いられやすい. そのため, 多くの場合において，「規定」と「規程」を区別する ためには，直前の単語だけに注目すればよいといえ る。ただし、「経過措置に関する規定」や「業務の運 営に関する規程」のように,「に関する」は「規定」 と「規程」のいずれにも先立って出現できる. その ため, 直前以外の単語にもある程度の重要度を割り 当てたと考えられる.

（2）前方にある単語列に比較的強く依存 この類型に属する法令用語集合の多くは，動詞（句） の集合である．たとえば，ID11（\{推定する，みな 
表 5 各法令用語集合における素性の重要度

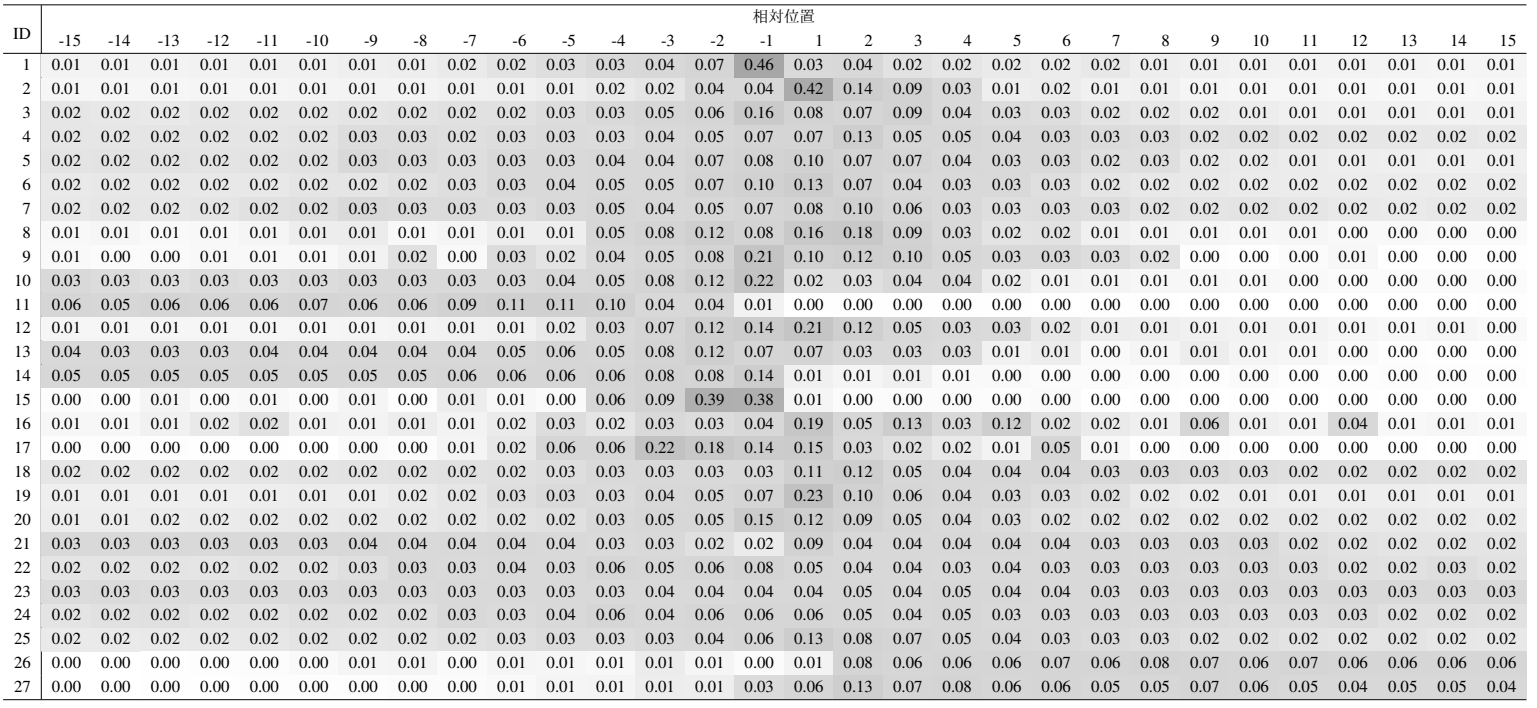

す \}）やID14（\{することができる，しなければな らない, するものとする $\}$ ）である. 動詞（句）は文 末に出現しやすいことを考えると，ごく自然な結果 である。

（3）後方にある単語列に比較的強く依存

ID26（\{前項の場合において, 前項に規定する場合に おいて $\})$ ，ID27（\{ただし,この場合において $\})$ な どがこの分類に属する.これらの法令用語は，前の 文を補足するために用いる接続詞句であるため，文 頭に現れやすい. そのため, 後方の単語列に強く注 目していることが考えられる.

(4) 前方と後方の単語列の両方にまんべんなく依存 ID3（\{者, 物, もの $\}), I D 9 （\{$ 科する, 処する, 課 する $\}$ ) ID18（\{当該, その $\})$, ID23（\{又は, 若し くは\}）など，さまざまな法令用語集合がこの類型 に属する．類型 (1) に属する法令用語のように強力 な手がかりとなる語が直前・直後に存在せず，また， 類型 (2) や類型 (3) に属する法令用語のように文頭 や文末に現れやすいわけではないため，前後の文脈 をまんべんなく使用して予測していると考えられる. 以上より，ランダムフォレストは，法令用語を同定する ための鍵となる単語がよく現れる位置や法令用語が文中 においてよく現れる位置に注目して分類器を構築してい るといえる.

\section{$6 \cdot 3$ 法令用語予測の難易度}

ある法令用語集合に対する予測の難易度は，さまざま な要因の影響を受ける. 主な要因は, (1) 機械的な区別の 実現性，(2) 用語選択を確定するために必要な文脈の範 囲, (3) 事例が出現する頻度の均衡性である.これらにつ いて，表 6 を用いて説明する．表 6 において, “vLBL+” は vLBL+vLBL(c)を表す.

(1)について，機械的な区別が可能であれば，単純な ルールで十分に分類できるため，法令用語の予測は容易
になる．このような法令用語集合の代表例は，法令用語 集合 ID1（\{規定, 規程 $\}$ ）である. 前節で議論したよう に,「規定」と「規程」の直前に現れる単語はある程度限 定されているうえ，それぞれの直前には異なる単語が来 やすい. そのため, 単純なルールであっても比較的良好 に予測できることが予想される.

また, ID17（\{改める, 改正する $\}$ ) についても, 前者 は「第五条中「A」を「B」に改める。」のように法令内 の表現を修正する際に用いられる反面, 後者は「○○法 の一部を次のように改正する。」のように法令全体を修 正する際に用いられるため, 同様に単純なルールで区別 可能であると考えられる.

表 6 から，ランダムフォレスト，ニューラル言語モデ ルを問わず，これらの法令用語を正確に予測できたこと がわかる，一方，その他の法令用語集合の多くは，この ような形で機械的に区別することは容易ではなく, 前後 の文脈から意味をつかまなけれなばらない.

(2)について, 用語の確定に必要となる文脈の範囲は法 令用語集合によってさまざまであるが，必要となる文脈 が少ないほど予測が容易になることは自明である。例え ば, ID1（\{規定, 規程 $\}$ ) は, 前述したように, 当該法 令用語の直前数単語から十分に予測可能であるといえる. また, ID23（\{又は, 若しくは $\})$ や ID24（\{及び, 並び に\}）の等位接続詞は, 原則的に当該法令用語を含む文 のみから予測可能である.これらの法令用語は, 並列構 造の階層を明らかにするために使い分けられるが, この 使い分けは，単一の文内で完結するためである．ただし， 法令文が長い, または並列構造が複雑な場合, 前後数単 語から正確に予測できない場合がある.

次に, ID27（\{ただし,この場合において $\}$ ）など，文 と文をつなぐ役割を持つ法令用語を厳密に決定するため には, 当該法令用語を含む文の直前の文が最低限必要に なると考えられる. ところが, 表 6 において, これらの 法令用語における正解率の最低值は $77.82 \% （ \mathrm{vLBL}+の$ 
表 6 法令用語ごとの正解率（マイクロ平均）

\begin{tabular}{l|r|rr}
\hline 法令用語 & 出現頻度 & RF $($ 可変） & vLBL+ \\
\hline \hline 規定 & 13,625 & $\mathbf{9 9 . 9 4 \%}$ & $99.20 \%$ \\
規程 & 164 & $90.24 \%$ & $\mathbf{9 8 . 1 7 \%}$ \\
$a c c_{\text {micro }}$ & & $99.83 \%$ & $99.19 \%$ \\
\hline \hline 改める & 213 & $\mathbf{1 0 0 . 0 \%}$ & $98.12 \%$ \\
改正する & 830 & $\mathbf{1 0 0 . 0 \%}$ & $\mathbf{1 0 0 . 0 \%}$ \\
$a c c_{\text {micro }}$ & & $\mathbf{1 0 0 . 0 \%}$ & $99.62 \%$ \\
\hline \hline 又は & 11,347 & $\mathbf{9 9 . 3 2 \%}$ & $75.47 \%$ \\
若しくは & 2,848 & $51.62 \%$ & $\mathbf{7 1 . 5 2 \%}$ \\
$a c c_{\text {micro }}$ & & $\mathbf{8 9 . 7 5 \%}$ & $74.68 \%$ \\
\hline \hline 及び & 10,539 & $\mathbf{9 9 . 6 8 \%}$ & $83.10 \%$ \\
並びに & 1,640 & $66.59 \%$ & $\mathbf{8 3 . 3 5 \%}$ \\
$a c c_{\text {micro }}$ & & $\mathbf{9 5 . 2 2 \%}$ & $83.13 \%$ \\
\hline \hline ただし & 1,497 & $\mathbf{9 8 . 2 6 \%}$ & $77.82 \%$ \\
この場合において & 649 & $\mathbf{8 7 . 3 7 \%}$ & $87.21 \%$ \\
$a c c_{\text {micro }}$ & & $\mathbf{9 4 . 9 7 \%}$ & $80.66 \%$ \\
\hline \hline 直ちに & 82 & $\mathbf{6 8 . 2 9 \%}$ & $57.32 \%$ \\
速やかに & 110 & $37.27 \%$ & $\mathbf{4 2 . 7 3 \%}$ \\
遅帯なく & 221 & $\mathbf{9 3 . 6 7 \%}$ & $65.61 \%$ \\
$a c c_{\text {micro }}$ & & $\mathbf{7 3 . 6 1 \%}$ & $57.87 \%$ \\
\hline & & & \\
\hline & & & \\
\hline
\end{tabular}

「ただし」）であり，正解率が極端に低いわけではない. これは，直前の文を用いなくても，同一の文における法 令用語周辺の文脈からこれらの法令用語を統計的に予測 できることを示唆する.

最後に, ID21（\{直ちに, 速やかに, 遅滞なく $\}$ ）は，使 い分けのルールが $2 \cdot 2$ 節のように定まっているものの, 用語決定のための統一的な基準はなく, 法案作成者の裁 量によって使用する用語を決定する面が大きい。そのた め, 訓練データを用いて法令用語の傾向をつかむことは できても，法令用語を正確に決定することは不可能であ ると考えられる．実際に，表 6 において，いずれの手法 も他の法令用語集合と比べて正解率が低い傾向にある.

(3)について，一般に，各クラスに属する事例の数が 極端に異なると, 多数派のクラスに不当に分類されやす くなる.そのため, 少数派の法令用語に対する予測性能 は低下する．表 6 においても，「若しくは」，「並びに」， 「直ちに」,「速やかに」などの少数派の法令用語の正解率 は,「又は」,「及び」,「遅滞なく」など多数派の法令用語 の正解率と比べて低い傾向がある. 一方で, 出現頻度に 大きな差が生じていても, ID1（\{規定, 規程 $\}$ ）や ID17 （\{改める, 改正する $\})$ など, 機械的な区別が可能な法 令用語については，多数派への偏りが緩やかである．不 均衡データの対処について，次節で議論する.
表 7 低頻度・高頻度の法令用語に対する正解率

\begin{tabular}{l|cc}
\hline 手法 & \multicolumn{2}{|c}{ 正解率の平均 } \\
& 低頻度 & 高頻度 \\
\hline \hline RF (可変, US) & $\mathbf{7 9 . 8 4 \%}$ & $89.40 \%$ \\
RF (可変, 重み) & $72.05 \%$ & $95.95 \%$ \\
\hline RF (可変) & $72.89 \%$ & $\mathbf{9 6 . 0 0 \%}$ \\
vLBL(c) & $72.17 \%$ & $88.65 \%$ \\
vLBL+vLBL(c) & $76.60 \%$ & $85.35 \%$ \\
\hline
\end{tabular}

\section{4 不均衡データの影響}

前節で述べたとおり，同じ法令用語集合に属する法令 用語の出現回数に大きな差が生じるとき，多数派の法令 用語を不当に出力しやすくなる場合がある.この問題に 対処するために，次の 2 通りの対策を講じる.

(1) 訓練データに対しアンダーサンプリングを施す. ある法令用語集合に対する事例について，出現頻度 が最も低い法令用語の出現回数分だけその他の法令 用語をランダムにサンプリングすることによって， すべての法令用語に対する事例の数を均等にする. たとえば，訓練データにおいて，ID24（\{及び，並 びに））の法令用語「及び」，「並びに」はそれぞれ 290,921 回，47,944 回出現するため,「及び」の全事 例から 47,944 個サンプリングする.

(2) 訓練データに対し，法令用語の出現割合に応じて 重み付けする。

ある法令用語集合に対する分類器を構築する際，そ れぞれの法令用語が出現する割合の逆数に基づいた 重み付けを各クラスの事例に加えることによって， 多数派のクラスにペナルティを与える.たとえば, 訓練データにおいて，「及び」，「並びに」はそれぞ れ 290,921 回，47,944 回出現するため，それぞれの クラスの事例に $(290921+47944) / 290921 \approx 1.165$, $(290921+47944) / 47944 \approx 7.068$ の重みを加える. 実験で用いた Scikit-learn の実装においては，各ク ラスの事例の出現頻度に上述の式で計算した重みが 乗算される．たとえば，決定木のあるノードに「及 び」,「並びに」の事例がそれぞれ 200 件，100 件属 している場合，重み付け後の值はそれぞれ約 233, 約 707 となり,「並びに」が多数派になる.

アンダーサンプリング，重み付けを施した訓練データを 用いて RF（可変）を構築し，5.1 節で示したテストデー タに出現する法令用語を予測した．不均衡データへの効 果を検証するために，各々の法令用語集合において，最 も出現頻度の低い法令用語と最も出現頻度の高い法令用 語に対して正解率を求め，それぞれマクロ平均を取った。 表 7 にその結果を示す。ここで,「US」,「重み」は，それ ぞれアンダーサンプリング，重み付けを表す。

表 7 より，低頻度の法令用語に対する RF（可変，US） の正解率は, RF (可変) と比べて 6.95 ポイント向上し 
表 8 正解率のマイクロ平均とマクロ平均

\begin{tabular}{l|rrr}
\hline 手法 & $a c c_{\text {micro }}$ & $a c c_{\text {macro-s }}$ & $a c c_{\text {macro-w }}$ \\
\hline \hline RF (可変, US) & $92.20 \%$ & $88.65 \%$ & $84.04 \%$ \\
RF (可変, 重み) & $95.24 \%$ & $93.14 \%$ & $84.28 \%$ \\
\hline RF (可変) & $\mathbf{9 5 . 3 7 \%}$ & $\mathbf{9 3 . 2 2 \%}$ & $\mathbf{8 4 . 6 8 \%}$ \\
vLBL(c) & $91.38 \%$ & $86.32 \%$ & $80.67 \%$ \\
vLBL+vLBL(c) & $90.95 \%$ & $85.62 \%$ & $81.12 \%$ \\
\hline
\end{tabular}

た。また, vLBL(c), vLBL+vLBL(c) と比べてもそれぞ れ 7.67 ポイント, 3.24 ポイント高く, RF (可変, US) が比較手法の中で最もよい正解率を達成した。一方，高 頻度の法令用語に対する RF（可変，US）の正解率は, vLBL(c), vLBL+vLBL(c) と比べるとそれぞれ 0.75 ポイ ント, 4.05 ポイント高かったものの, RF（可変）と比べ て 0.64 ポイント低下した。 RF（可変，重み）において は，低頻度の法令用語に対する正解率が 0.84 ポイント減 少し，想定した効果は見られなかった。

次に，各々の法令用語に対する正解率のマイクロ平均 $\left(a c c_{\text {micro }}\right)$, 法令用語集合単位のマクロ平均 $\left(a c c_{\text {macro-s }}\right)$, 法令用語単位のマクロ平均 $\left(a c c_{\text {macro-w }}\right)$ を表 8 に示す。す なわち，いずれの指標においても, RF（可変，US）は RF (可変) の值を下回ったが, $\operatorname{vLBL}(\mathrm{c})$ および $\mathrm{vLBL}+\mathrm{vLBL}(\mathrm{c})$ の值を上回った.

以上より，アンダーサンプリングの効果を認めること はできるが，マイクロ平均やマクロ平均における全体的 な予測性能向上のためには，手法をより洗練させる必要 がある。

\section{7. ま と め}

本論文では，法制執務規則に定義されている法令用語 集合を対象とした法令用語校正問題を定義した。さらに， 法令用語集合を選択肢と考えることにより，この問題を 選択肢付き穴埋め問題に還元した。また，本論文では， 法令用語集合ごとに最適化したランダムフォレスト分類 器 [Breiman 01] を用いて本問題を解く手法を提案した. 実験によって，本手法はニューラル言語モデルを用いた 既存の単語予測手法よりも高い性能を発揮することを示 した。

今後は， 6.4 節で述べたように，高頻度の法令用語に 対する正解率を保ちつつ，低頻度の法令用語に対する正 解率を向上させるために，手法を改善することを目指す. また，近年 ELMo [Peters 18] や BERT [Devlin 19] など, 大量のコーパスによって事前学習された汎用の言語表現 機構が提案され，さまざまなタスクに対して高い性能を 発揮することが示されている，そこで，法令用語校正問 題においてもこれらの機構を導入したい.
謝辞

本研究の一部は JSPS 科研費 JP18H03492, JP17K00460

の助成を受けた。

\section{$\diamond$ 参 考 文 献 $\diamond$}

[Bengio 03] Bengio, Y., Ducharme, R., Vincent, P., and Jauvin, C.: A neural probabilistic language model, Journal of Machine Learning Research, Vol. 3, pp. 1137-1155 (2003)

[Breiman 01] Breiman, L.: Random forests, Machine Learning, Vol. 45, pp. 5-32 (2001)

[Devlin 19] Devlin, J., Chang, M.-W., Lee, K., and Toutanova, K.: BERT: Pre-training of deep bidirectional transformers for language understanding, in Proceedings of the 2019 Conference of the North American Chapter of the Association for Computational Linguistics: Human Language Technologies, pp. 4171-4186 (2019)

[Elman 03] Elman, J. L.: Finding structure in time, Cognitive Science, Vol. 14, No. 2, pp. 179-211 (2003)

[Freund 97] Freund, Y. and Schapire, R. E.: A decision-theoretic generalization of on-line learning and an application to boosting, Journal of Computer and System Sciences, Vol. 55, No. 1, pp. 119-139 (1997)

[Gubbins 13] Gubbins, J. and Vlachos, A.: Dependency language models for sentence completion, in Proceedings of the 2013 Conference on Empirical Methods in Natural Language Processing, pp. 1405-1410 (2013)

[ぎょうせい 13] ぎょうせい: 全訂 図説法制執務入門,ぎょうせ い(2013)

[法制 18] 法制執務研究会 : ワークブック法制執務（新訂第二版）, ぎょうせい (2018)

[石毛 12] 石毛 正純 : 法制執務詳解《新版 II》,ぎょうせい (2012)

[礒崎 06] 礒崎 陽輔 : 分かりやすい法律・条例の書き方,ぎょうせ い (2006)

[Jordan 86] Jordan, M. I.: Serial order: a parallel distributed processing approach, Technical Report ICS Report 8604, 39 pages, Institute for Cognitive Science, University of California (1986)

[Katz 87] Katz, S. M.: Estimation of probabilities from sparse data for the language model component of a speech recognizer, IEEE Transactions on Acoustics, Speech, and Signal Processing, Vol. 35, No. 3, pp. 400-401 (1987)

[Kingma 15] Kingma, D. P. and Ba, J.: Adam: A method for stochastic optimization, in International Conference on Learning Representations, 15 pages (2015)

[Mikolov 13] Mikolov, T., Chen, K., Corrado, G., and Dean, J.: Efficient estimation of word representations in vector space, in International Conference on Learning Representations, 12 pages (2013)

[Mirowski 15] Mirowski, P. and Vlachos, A.: Dependency recurrent neural language models for sentence completion, in Proceedings of the 53rd Annual Meeting of the Association for Computational Linguistics, pp. 511-517 (2015)

[Mnih 13] Mnih, A. and Kavukcuoglu, K.: Learning word embeddings efficiently with noise-contrastive estimation, Advances in Neural Information Processing Systems 26, pp. 2265-2273 (2013)

[森 15] 森洸樹, 三輪 誠, 佐々木 裕 : 語順と共起を考慮したニュー ラル言語モデルによる英文穴埋め, 言語処理学会 第 21 回年次大 会 発表論文集, pp. 760-763 (2015)

[Peters 18] Peters, M., Neumann, M., Iyyer, M., Gardner, M., Clark, C., Lee, K., and Zettlemoyer, L.: Deep contextualized word representations, in Proceedings of the 2018 Conference of the North American Chapter of the Association for Computational Linguistics: Human Language Technologies, pp. 2227-2237 (2018)

[Woods 16] Woods, A. M.: Exploiting linguistic features for sentence completion, in Proceedings of the 54th Annual Meeting of the Association for Computational Linguistics, pp. 438-442 (2016)

[Zweig 11] Zweig, G. and Burges, C. J.: The microsoft research sentence completion challenge, Technical Report, Microsoft Research, 7 pages (2011)

〔担当委員 : 平 博 順〕 
2019 年 5 月 8 日 受理

$\diamond$ 付 録 $\diamond$

\section{A. 法令用語集合}

定義した法令用語集合を (1) 名詞，(2)動詞（句），(3) 形容詞（句）, (4) 副詞（句），(5) 接続詞（句）に分けて，それぞれ表 A.1 から表 A.5 に示す. 表 A.1 から表 A.5 における各法令用語の出現頻度は, 単語結合を施した後の数である.

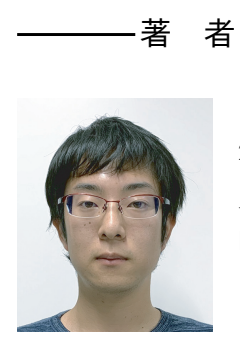

\section{者 紹}

山腰 貴大(学生会員)

2018 年名古屋大学大学院情報科学研究科博士前期課程修 了. 修士 (情報科学) . 同年より, 同大学院情報学研究科 博士後期課程に在籍. 自然言語処理, 特に文書作成支援に 関心がある，言語处理学会，情報処理学会各会員。

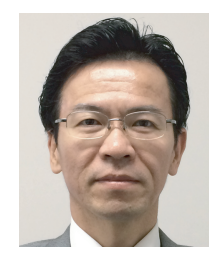

小川 泰弘(正会員)

1995 年名古屋大学工学部情報工学科卒業. 2000 年同大 学院工学研究科情報工学専攻博士課程後期課程修了。博士 (工学). 同年より, 名古屋大学大学院工学研究科助手. 現 在, 同大学情報基盤センターおよび大学院情報学研究科准 教授.自然言語処理に関する研究に従事. 近年は膠着語間 の機械翻訳および法令文書処理に関する研究に関心を持つ。 言語処理学会, 情報処理学会, 電子情報通信学会各会員.

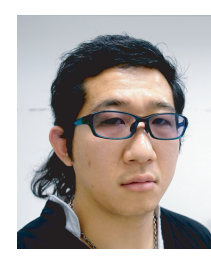

駒水 孝裕(正会員)

2009 年筑波大学第三学群情報学類卒業. 2015 年同大学院 システム情報工学研究科博士後期課程修了. 博士（工学）。 同年より, 同大学計算科学研究センター研究員. 現在, 名 古屋大学情報基盤センター助教. データ工学に関する研究 に従事. 近年はオープンデータの利活用のための基盤技術 や応用研究に関心を持つ. ACM, IEEE, 日本データベース 学会, 情報処理学会, 電子情報通信学会, 言語処理学会各 会員.

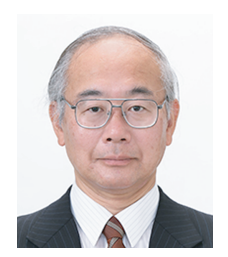

\section{外山 勝彦 (正会員)}

1984 年名古屋大学工学部電気学科卒業. 1989 年同大学院 工学研究科情報工学専攻博十課程満了, 名古屋大学工学部 助手, 中京大学情報科学部講師, 同助教授. 名古屋大学大 学院工学研究科助教授を経て, 2003 年同情報科学研究科 助教授. 2007 年同准教授. 現在，同大学情報基盤センター および大学院情報学研究科教授. 工学博士. 論理に基づく 知識処理, 自然言語処理に関する研究に従事. 近年は法制 執務支援や法令翻訳支援に関心を持つ。電子情報通信学会, 情報処理学会, 言語処理学会各会員.
表 A.1 名詞の法令用語集合

\begin{tabular}{|c|c|c|c|c|c|}
\hline ID & 法令用語 & 出現頻度 & ID & 法令用語 & 出現頻度 \\
\hline \multirow[t]{2}{*}{1} & 規定 & 401,381 & \multirow[t]{4}{*}{5} & 通知 & 17,894 \\
\hline & 規程 & 4,139 & & 通報 & 768 \\
\hline \multirow[t]{3}{*}{2} & 場合 & 188,970 & & 報告 & 16,675 \\
\hline & とき & 127,861 & & 連絡 & 1,475 \\
\hline & 時 & 17,808 & \multirow[t]{4}{*}{6} & 命令 & 15,176 \\
\hline \multirow[t]{3}{*}{3} & 者 & 353,279 & & 指揮 & 570 \\
\hline & 物 & 29,689 & & 指示 & 3,034 \\
\hline & もの & 231,715 & & 監督 & 3,732 \\
\hline \multirow[t]{5}{*}{4} & 許可 & 24,145 & \multirow[t]{2}{*}{7} & 要請 & 1,671 \\
\hline & 認可 & 15,677 & & 要求 & 1,606 \\
\hline & 届出 & 22,021 & \multirow[t]{3}{*}{8} & 施行 & 233,058 \\
\hline & 認証 & 1,949 & & 適用 & 83,062 \\
\hline & & & & 準用 & 2,041 \\
\hline
\end{tabular}

表 A.2 動詞（句）の法令用語集合

\begin{tabular}{r|lr}
\hline ID & 法令用語 & 出現頻度 \\
\hline \hline \multirow{2}{*}{9} & 科する & 1,212 \\
& 処する & 4,841 \\
& 課する & 4,320 \\
\hline \multirow{2}{*}{10} & 適用する & 21,119 \\
& 準用する & 66,303 \\
& 例による & 4,368 \\
\hline \multirow{2}{*}{11} & 推定する & 228 \\
& みなす & 20,039 \\
\hline \multirow{2}{*}{12} & とする & 131,314 \\
& である & 58,020 \\
\hline \multirow{2}{*}{13} & することができない & 6,783 \\
& してはならない & 4,457 \\
\hline \multirow{2}{*}{14} & することができる & 29,348 \\
& しなければならない & 42,679 \\
& するもの する & 11,501 \\
\hline \multirow{2}{*}{15} & この限りでない & 7,380 \\
& 妨げない & 1,419 \\
\hline \multirow{2}{*}{16} & なお 従前の 例による & 36,402 \\
& なお 効力を 有する & 2,734 \\
\hline \multirow{2}{*}{17} & 改める & 6,941 \\
& 改正する & 24,349 \\
\hline & &
\end{tabular}


表 A.3 形容詞（句）の法令用語集合

\begin{tabular}{l|lr}
\hline ID & 法令用語 & 出現頻度 \\
\hline \hline \multirow{2}{*}{18} & 当該 & 297,904 \\
& その & 213,114 \\
\hline \multirow{2}{*}{19} & に係る & 161,564 \\
& に 関する & 120,076 \\
& に 関係する & 80 \\
\hline \multirow{2}{*}{20} & の & $2,813,563$ \\
& に 規定する & 169,742 \\
& の 規定 による & 113,123 \\
\hline
\end{tabular}

表 A.4 副詞（句）の法令用語集合

\begin{tabular}{r|lr}
\hline ID & 法令用語 & 出現頻度 \\
\hline \hline 21 & 直ちに & 2,414 \\
& 速やかに & 2,229 \\
& 遅帯なく & 6,549 \\
\hline \multirow{2}{*}{22} & に基づき & 8,883 \\
& により & 205,212 \\
\hline
\end{tabular}

表 A.5 接続詞（句）の法令用語集合

\begin{tabular}{l|lr}
\hline ID & 法令用語 & 出現頻度 \\
\hline \hline \multirow{2}{*}{23} & 又は & 337,058 \\
& 若しくは & 88,241 \\
\hline \multirow{2}{*}{24} & 及び & 301,460 \\
& 並びに & 49,584 \\
\hline \multirow{2}{*}{25} & その他の & 55,391 \\
& その他 & 29,163 \\
\hline \multirow{2}{*}{26} & 前項の 場合において & 2,834 \\
& 前項に 規定する 場合において & 325 \\
\hline \multirow{2}{*}{27} & ただし & 39,234 \\
& この 場合において & 20,788 \\
\hline
\end{tabular}

